\title{
Immunohistochemical Study of BCL2 Protein, Oestrogen Receptor Alpha and Oestrogen Receptor Beta Expression in Adenocarcinoma Prostate and Benign Prostatic Hyperplasia
}

\author{
Aria Jyothi Appukuttan ${ }^{1}$ \\ ${ }^{1}$ Department of Pathology, Government T.D. Medical College, Alappuzha, Kerala, India.
}

\section{ABSTRACT}

\section{BACKGROUND}

Oestrogens are involved in the prostate carcinogenesis and neoplastic progression. Overproduction of B-Cell Lymphoma-2 Gene (BCL2) protein contributes to inhibition of apoptosis, prolongation of cell cycle and neoplastic expansion. In this study, the investigator has tried to characterize the expression of BCL2 in benign prostatic hyperplasia (BPH) and adenocarcinoma prostate and tried to assess the role of BCL2 as a prognostic factor in carcinoma prostate by comparing with Gleason score. Another objective was to study the oestrogen receptor alpha and beta expression in adenocarcinoma prostate.

\section{METHODS}

In this retrospective study, immunostaining of BCL2 is done in carcinoma prostate and BPH and compared with Gleason score. Immunohistochemical staining of oestrogen receptor alpha (ER $\alpha$ ) and oestrogen receptor beta (ER $\beta$ ) were studied in stromal and epithelial cells of carcinoma prostate and BPH.

\section{RESULTS}

A total of 35 cases of adenocarcinoma and 35 cases of BPH was studied. 13 high grade adenocarcinoma and 2 intermediate carcinoma and 10 cases of BPH showed BCL-2 positivity. ER $\beta$ was present in epithelium in all cases and in stroma of 15 cases of carcinoma. In BPH, ER $\beta$ was present in the epithelium of 21 cases and in stroma of 8 cases. ER $\alpha$ was present in epithelium in 3 cases and in stroma of 10 cases of carcinoma. In BPH, ER $\alpha$ is present in the epithelium of 21 cases and in stroma of 8 cases.

\section{CONCLUSIONS}

All prostatic carcinoma with a high Gleason grade showed BCL-2 positivity. This suggests that BCL-2 positivity in prostatic carcinoma may be considered as a prognostic marker. The ER $\beta$ expression in epithelium of prostate carcinoma is much higher compared to BPH with a significant $\mathrm{P}$ value $<0.01$. This reveals the role of ER $\beta$ expression in proliferating and neoplastic prostate.

\section{KEY WORDS}

Oestrogen Receptors, BCL-2, Carcinoma Prostate, Benign Prostatic Hyperplasia, Immuno Histochemical Staining, Gleason Score
Corresponding Author: Dr. Aria Jyothi Appukuttan, Assistant Professor, Department of Pathology, Government T.D. Medical College, Alappuzha, Kerala, India.

E-mail: drariajyothi@gmail.com

DOI: $10.14260 /$ jemds/2021/39

How to Cite This Article:

Appukuttan AJ. Immunohistochemical study of bcl2 protein, oestrogen receptor alpha and oestrogen receptor beta expression in adenocarcinoma prostate and benign prostatic hyperplasia. J Evolution Med Dent Sci 2021;10(04):179-184, DOI: 10.14260/jemds/2021/39

Submission 25-09-2020,

Peer Review 23-11-2020

Acceptance 30-11-2020,

Published 25-01-2021.

Copyright (C) 2021 Aria Jyothi Appukuttan. This is an open access article distributed under Creative Commons Attribution License [Attribution 4.0 International (CC $B Y 4.0)]$ 


\section{BACKGROUND}

Human prostate has a remarkably high incidence of hyperplasia \& neoplastic disease. ${ }^{1}$ Carcinoma of prostate is the most common cause of internal malignancy in men and is responsible for $10 \%$ cancer deaths. Benign prostatic hyperplasia (BPH) occurs in approximately $70 \%$ of men over 70 years age. It develops at a time when the testosterone levels are falling and oestrogen levels are rising thus resulting in an increase in oestrogen androgen ratio. ${ }^{2}$ For oestrogen to be directly involved in the genesis of human $\mathrm{BPH}$, the prostate must contain oestrogen receptors, oestrogen receptor alpha $(\mathrm{ER} \alpha)$ and oestrogen receptor beta $(\mathrm{ER} \beta) .^{3}$

Oestrogen receptors belong to the steroid hormone superfamily of nuclear receptors. Oestrogen signalling is stimulated or inhibited depending on the balancing action of ER $\alpha$ and ER $\beta$ on target organs. ER $\alpha$ gene is located on the chromosome 6. It has 595 amino acids and a molecular size of $66 \mathrm{kDa}$. ER $\beta$ gene is located on chromosome 14. It has 530 amino acids and a molecular size of $54 \mathrm{kDa}^{4}$ Oestrogen receptors are believed to play a significant role in prostatic carcinoma. Majority of prostatic adenocarcinoma and BPH showed nuclear immunoreactivity for ER $\beta$ in both tumour and stromal cells.

BCL-2 family of proteins contribute to programmed cell death or apoptosis. It is a large protein family and all members contain at least one of four BCL-2 homology domains. Some members including BCL-2, B-cell lymphoma-extra-large (BCL$\mathrm{XL}$ ), medial collateral ligament (MCL-I) are antiapoptotic. Some other members of the family like $B A X, B A K, B O K$ are proapoptotic. ${ }^{5}$ The $B C L 2$ gene product regulates programmed cell death. It is involved in the selection and maintenance of long living cells rescuing them from apoptotic cell death. $B C L$ 2 (B-Cell Lymphoma-2 Gene) was first discovered in follicular B-cell lymphoma linked to $t(14 ; 18)$ translocation ${ }^{6}$ this gene is located on chromosome segment 18q21.3. There are extrinsic and intrinsic pathways which can lead to apoptosis. The intrinsic cell death pathway is evoked by injury to cell by radiation, cytotoxic drugs, growth factor withdrawal or by cytokine deprivation. Damaged mitochondria will release cytochrome C. This will bind with the adaptor molecule Apoptotic protease-activating factor-1 (APAF-1) and an inactive initiator caspase, procaspase 9. This will trigger a cascade of caspases activation. This will result in the morphological and biochemical changes associated with apoptosis. Extrinsic pathway functions independently of mitochondria. It is activated by cell surface death receptors (CD95 or FAS). They are located on the plasma membrane. They directly activate the caspase cascade via the recruitment of initiator caspase-8. Deregulation and overproduction of BCL2 protein occurs in a wide variety of human cancers. Immunohistochemical analysis of BCL2 protein levels in carcinoma prostate has revealed a correlation between the presence of BCL2 protein and resistance to anti androgen therapy. ${ }^{7}$ Elevated levels of BCL2 protein may contribute to the progression of prostatic cancers to a metastatic and hormone insensitive state characterised by poor response to chemotherapy. ${ }^{8}$ Over expression of mutant BCL2 proteins prolongs cell survival despite exposure to damaging agents. ${ }^{6}$ Such abnormal exposure of BCL2 protein may be the cause of radiation therapy failure.
The purpose of this study was to investigate the expression and prognostic value of BCL2, ER $\alpha$ and ER $\beta$ in the development of BPH and prostatic carcinoma. The role of BCL2 as a prognostic factor in carcinoma prostate was studied and was compared with Gleason score.

\section{METHODS}

The study was designed as a retrospective study. The study was conducted at Department of Pathology and Department of Urology of Govt. T.D. Medical College, Alappuzha. The study population included all prostatic biopsy specimens of patients of Department of Urology, Govt. T.D. Medical College, Alappuzha.

All TruCut biopsy specimens received in the pathology department of Govt. T.D. Medical College Alappuzha from October 2014 to September 2015 with a histological diagnosis of prostatic carcinoma were taken. An equal number of cases of BPH were also included. Specimens that were not properly fixed and unsuitable for immunohistochemical study were excluded. Specimens in which extra sections cannot be taken for immunohistochemical study were also excluded.

All TruCut biopsies of prostate received in the department were stained with haematoxylin \& eosin. The cases with diagnosis of adenocarcinoma prostate during the period of study were recruited into the study. Then an equal number of cases of BPH were selected. Immunohistochemical expression of BCL2, ER $\alpha$ and ER $\beta$ were done in all cases. Cases of adenocarcinoma were graded for its differentiation using Gleason grading system and compared with BCL2 expression.

\begin{tabular}{|c|c|}
\hline Grade & Description \\
\hline 1 & $\begin{array}{c}\text { Single, separate, uniform glands in closely packed masses with a definite, } \\
\text { usually rounded, edge limiting the area of tumour }\end{array}$ \\
\hline 2 & $\begin{array}{c}\text { Single, separate, slightly fewer uniform glands, loosely packed with less } \\
\text { sharp edge. }\end{array}$ \\
\hline 3a & $\begin{array}{l}\text { Single, separate, much more variable glands, may be closely packed but } \\
\text { usually irregularly separated, ragged, poorly defined edges }\end{array}$ \\
\hline 3b & Like $3 a$, but very small glands or tiny cell clusters. \\
\hline $3 c$ & $\begin{array}{l}\text { Sharply and smoothly circumscribed rounded masses of papillary or loose } \\
\text { cribriform tumour ('papillary intraductal tumour') }\end{array}$ \\
\hline $4 \mathrm{a}$ & Raggedly outlined, raggedly infiltrating, fused glandular tumour. \\
\hline $4 \mathrm{~b}$ & Like 4a, with large pale cells ('hypernephroid') \\
\hline $5 a$ & $\begin{array}{l}\text { Sharply circumscribed, rounded masses of almost solid cribriform tumour, } \\
\text { usually with central necrosis comedocarcinoma') }\end{array}$ \\
\hline $5 b$ & $\begin{array}{c}\text { Ragged masses of anaplastic carcinoma with only enough gland formation } \\
\text { or vacuoles to identify it as adenocarcinoma }\end{array}$ \\
\hline & $\begin{array}{l}\text { Table 1. Gleason Microscopic Grading System } \\
\text { for Prostatic Carcinoma }{ }^{9}\end{array}$ \\
\hline
\end{tabular}

Prostate cancer can have a range of growth patterns. The overall Gleason score is calculated by adding the score of the most common grade (primary grade pattern) and the second most common grade (secondary grade pattern). If only one pattern of growth is seen, it is multiplied by 2 for a final score. Total score of 8,9 or 10 is considered as high-grade tumour. Total score of 7 is considered as intermediate grade and total score of 6 as low grade.

Immunohistochemical staining with BCL2, ER $\alpha$ and ER $\beta$ were performed for each case as follows -

1. Sections dewaxed and rehydrated, then placed in Tris Ethylenediaminetetraacetic acid (EDTA) Borate buffer for antigen retrieval. 
2. Antigen retrieval done by heat method in pressure cooker for 10 minutes followed by cooling to room temperature.

3. Sections washed in water for 10 minutes.

4. Endogenous peroxidase abolished by submerging the slides in quenching solution $\left(30 \mathrm{~mL} 30 \% \mathrm{H}_{2} \mathrm{O}_{2}: 300 \mathrm{~mL}\right.$ distilled water) for 20 minutes and then washed in tap water for 5 minutes; rinsed in distilled water for 3 minutes and kept in Tris EDTA borate buffer for 5 minutes.

5. Sections dried by wiping all around.

6. Serum blocking solutions added and kept for 10 minutes.

7. Sections blotted and primary antibody added on to sections and incubated for 1 hour in a moist chamber, washed in phosphate-buffered saline (PBS) for 5 minutes for 3 times.

8. Sections treated with super enhancer and kept for 25 minutes.

9. Secondary antibody added and incubated for 25 minutes. PBS wash for 2 minutes for 3 times.

10. Chromogen Diaminobenzidine (DAB) added. (Constituted by mixing $1 \mathrm{~mL}$ buffer, 50 microlitre liquid DAB) and kept for 5 minutes; washed in PBS for 5 minutes.

11. Sections rinsed in distilled water for 5 minutes; stained with Harris Haematoxylin by 10 dips and blued for 5 minutes.

12. Sections dehydrated, cleared and mounted with Dibutyl phthalate Polystyrene Xylene (DPX).

BCL2 is localised in the cytoplasm of the cells whereas ER $\alpha$ and ER $\beta$ are expressed in the nucleus. Their presence in the slide is visualised as brown colour. BCL2, ER $\alpha$ and ER $\beta$ expression by immunohistochemistry is tested in BPH and carcinoma prostate. The haematoxylin and eosin sections positive for carcinoma prostate graded and scored as per Gleason score. The sections stained with BCL2 were correlated with the Gleason score.

\section{Statistical Analysis}

Data was entered in open spread sheet analysed using SPSS statistical software. Qualitative variables like expression of BCL-2 protein, ER $\alpha$ and ER $\beta$ were expressed for frequency and percentage. Quantitative variables like Gleason score was expressed as mean and standard deviation. Chi-square test was used to analyse the association between adenocarcinoma prostate and $\mathrm{BPH}$, association between high grade and intermediate grade adenocarcinoma prostate. Chi-square test was also used to analyse the association between ER $\alpha$ expression in the epithelium and stroma of adenocarcinoma prostate and BPH. Another use of Chi-square test was to analyse association between ER $\beta$ expression in the epithelium and stroma of adenocarcinoma prostate and BPH. Independent $t$ test was used to compare Gleason score and BCL-2 expression. A P value $<0.05$ was considered to be statistically significant.

\section{RESULTS}

In the study, a total of 35 adenocarcinoma prostate and 35 cases of BPH were evaluated. 15 cases (42.9\%) of adenocarcinoma showed BCL-2 positivity and 20 cases (57.1 $\%$ ) were BCL-2 negative. In BPH, 10 cases (28.6 \%) showed
BCL-2 positivity and 25 cases (71.4\%) were BCL-2 negative. Chi square test was done to evaluate BCL-2 expression in adeno carcinoma prostate and BPH. Chi square test ( $\chi^{2}$ test) was done in evaluating BCL-2 expression in adenocarcinoma and BPH. $\chi^{2}$ test was 1.56 and P value 0.21. Since P value $>0.05$, it was not significant.

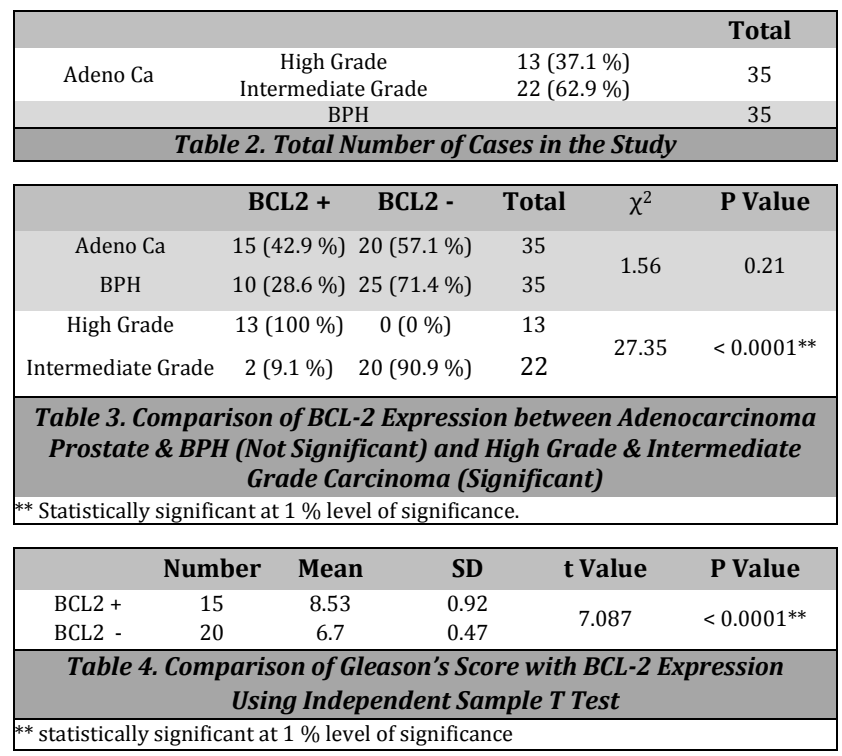

Out of 35 cases of adenocarcinoma prostate, 13 cases (37.1 \%) were high grade carcinoma. 22 cases (62.9\%) were intermediate grade carcinoma. Out of 15 cases of adenocarcinoma which showed BCL-2 positivity, 13 cases were high grade carcinoma. All high-grade adenocarcinoma showed BCL-2 positivity. Out of 22 cases of intermediate grade adenocarcinoma only 2 cases (9.1\%) showed BCL-2 positivity and 20 cases $(90.9 \%)$ of intermediate grade adenocarcinoma were BCL-2 negative. $\chi^{2}$ test done with a value 27.35. The $\mathrm{P}$ value was $<0.0001$. So, the BCL- 2 expression in high grade adenocarcinoma compared to intermediate carcinoma is statistically significant at $1 \%$ level of significance.

15 cases of adenocarcinoma showed BCL-2 positivity. Mean of Gleason score for these cases were 8.53 with a standard deviation 0.92 . In 20 cases which were negative for BCL-2 had a mean Gleason score of 6.7 with a standard deviation 0.4. Sample t test done with a value 7.087. P value was $<0.0001$. Hence BCL-2 positivity and high grade of adenocarcinoma prostate are related at $1 \%$ level of statistical significance. ER $\beta$ was present in the epithelium of all 35 cases $(100 \%)$ cases of adenocarcinoma prostate. All 13 high grade cases and 22 intermediate cases were positive. ER $\beta$ was present in epithelium of BPH in 21 cases $(60 \%)$ cases. $\chi^{2}$ test showed a value 17.5. $\mathrm{P}$ value was $<0.001$. So there is statistically significant association of epithelial expression of ER $\beta$ and adenocarcinoma prostate. ER $\beta$ expressed in stroma of 15 cases (42.9\%) of adenocarcinoma and 8 cases $(22.9 \%)$ of BPH. $\chi^{2}$ test done with a value 3.173. P value was 0.075 . As it is $>0.05$, no statistically significant association found. ER $\alpha$ present in epithelium of 3 cases of adenocarcinoma (8.6\%). All of which were of intermediate grade. But ER $\alpha$ was present in 21 cases $(60 \%)$ of BPH with a $\chi^{2}$ value 20.54 . P value was < 0.0001 . So, there is statistically significant association between ER $\alpha$ epithelial expression and BPH. 


\begin{tabular}{|c|c|c|c|c|c|c|c|c|c|}
\hline \multirow[b]{2}{*}{$\begin{array}{l}\text { ER } \beta \text { Present in } \\
\text { Epithelium }\end{array}$} & \multirow[b]{2}{*}{ Adeno Ca } & \multirow[b]{2}{*}{$\begin{array}{c}\text { High Grade } \\
\text { Intermediate Grade } \\
\text { BPH }\end{array}$} & \multicolumn{2}{|c|}{ Present } & \multicolumn{2}{|c|}{ Absent } & \multirow{2}{*}{$\begin{array}{c}\text { Total } \\
35 \\
35\end{array}$} & \multirow{2}{*}{$\begin{array}{c}\chi^{2} \\
17.5\end{array}$} & \multirow{2}{*}{$\begin{array}{l}\text { P Value } \\
<0.0001^{* *}\end{array}$} \\
\hline & & & $\begin{array}{l}13 \\
22\end{array}$ & $\begin{array}{c}35 \\
(100 \%) \\
\%)\end{array}$ & $\begin{array}{l}0 \\
0\end{array}$ & $\begin{array}{c}0 \\
(0 \%)\end{array}$ & & & \\
\hline \multirow{2}{*}{$\begin{array}{l}\text { ER } \beta \text { present in } \\
\text { stroma }\end{array}$} & \multirow[t]{2}{*}{ Adeno $\mathrm{Ca}$} & $\begin{array}{c}\text { High Grade } \\
\text { Intermediate Grade }\end{array}$ & $\begin{array}{c}13 \\
2\end{array}$ & $\begin{array}{c}15 \\
(42.9 \%)\end{array}$ & $\begin{array}{c}0 \\
20\end{array}$ & $\begin{array}{c}20 \\
(57.1 \%)\end{array}$ & 35 & 3.173 & 0.075 \\
\hline & & $\mathrm{BPH}$ & \multicolumn{2}{|c|}{$8(22.9 \%)$} & \multicolumn{2}{|c|}{$27(77.1 \%)$} & 35 & & \\
\hline \multirow{2}{*}{$\begin{array}{l}\text { ER } \alpha \text { present in } \\
\text { Epithelium }\end{array}$} & \multirow[t]{2}{*}{ Adeno Ca } & $\begin{array}{c}\text { High Grade } \\
\text { Intermediate Grade }\end{array}$ & $\begin{array}{l}0 \\
3\end{array}$ & $\begin{array}{c}3 \\
(8.6 \%)\end{array}$ & $\begin{array}{l}13 \\
19\end{array}$ & $\begin{array}{c}32 \\
(91.4 \%)\end{array}$ & 35 & 20.54 & $<0.0001^{* *}$ \\
\hline & & $\mathrm{BPH}$ & \multicolumn{2}{|c|}{$21(60 \%)$} & \multicolumn{2}{|c|}{$14(40 \%)$} & 35 & & \\
\hline \multirow{2}{*}{$\begin{array}{l}\text { ER } \alpha \text { Present in } \\
\quad \text { Stroma }\end{array}$} & \multirow[t]{2}{*}{ Adeno Ca } & $\begin{array}{c}\text { High Grade } \\
\text { Intermediate Grade }\end{array}$ & $\begin{array}{l}2 \\
8\end{array}$ & $\begin{array}{c}10 \\
(28.6 \%)\end{array}$ & $\begin{array}{l}11 \\
14\end{array}$ & $\begin{array}{c}25 \\
(71.4 \%)\end{array}$ & 35 & 0.0722 & 0.788 \\
\hline & & $\mathrm{BPH}$ & & & & & 35 & & \\
\hline
\end{tabular}

ER $\alpha$ present in stroma of 10 cases $(28.6 \%)$ of adenocarcinoma and 9 cases (25.7\%) of BPH. $\chi^{2}$ value was 0.0722 and $P$ value was 0.788 . As the $P$ value was $>0.05$, there is no statistically significant association.

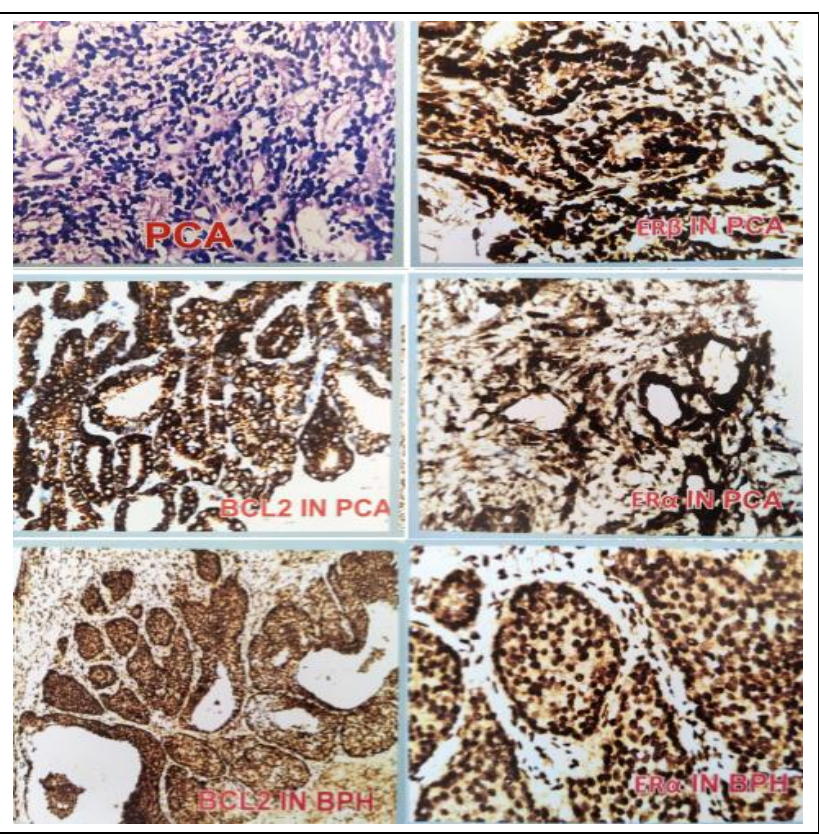

Figure PCA Shows Adenocarcinoma H \& E 40X, Figure ER $\beta$ in PCA Shows Immunohistochemical Staining of ER $\beta$ in Prostate Carcinoma, Figure BCL-2 in PCA Shows Immunohistochemical Staining of BCL-2 in

Prostate Carcinoma, Figure ER $\alpha$ Shows Immunohistochemical Staining of ER $\alpha$ in Prostate Carcinoma, Figure BCL-2 in BPH Shows Immunohistochemical Staining of BCL-2 in BPH, Figure ER $\alpha$ in BPH Shows Immunohistochemical Staining of ER $\alpha$ in BPH

\section{DISCUSSION}

Prostate cancer is the most common cancer and $2^{\text {nd }}$ leading cause of cancer related deaths in elderly men. The incidence increases with age and $70 \%$ are affected by 70 years. Carcinoma is not reported in case of pre pubertal castration. ${ }^{10}$ Similarly, remarkably low incidence is associated with hyper oestrogenism in liver cirrhosis. These findings suggest the possible association of carcinoma prostate and sex hormone levels. Moreover, many studies implicate oestrogens as the potential agents causing development and progression of prostate cancer. Benign Prostatic Hyperplasia (BPH) occurs in elderly men and the condition worsens as age advances. ${ }^{11}$ It affects $70 \%$ of men over 60 years old. Periurethral or transition zone nodules compress urethra and cause obstruction, urinary retention and infection. BPH is diagnosed when there is glandular and fibromuscular hyperplasia. ${ }^{12}$ Histologically, there is hyperplasia of glandular and stromal tissue with papillary buds, infoldings and cysts.

Actions of oestrogens are mediated by receptors namely, ER $\alpha$ and ER $\beta$. They are members of the nuclear receptor superfamily. ${ }^{13}$ There is $59 \%$ similarity in the aminoacid level between ER $\alpha$ and ER $\beta$ in the ligand binding domain. Both receptors bind the natural ligand $17 \beta$ estradiol with equal affinity. ${ }^{14}$ But phytoestrogens and selective oestrogen receptor modulators (SERM) can bind ER alpha and ER beta selectively. ${ }^{15}$ In the inactive state, ERs exist as monomers and bound to heat shock protein. In the active stage they form homo or heterodimers. Mechanism of action and expression of ER $\beta$ is encoded by chromosome locus $14 q 22-24.15$ In prostate, Oestrogen Receptor alpha (ER $\alpha$ ) is expressed in stromal and basal cells. Oestrogen Receptor beta (ER $\beta$ ) is expressed in epithelial and stromal cells. ER $\beta$ upregulates the expression of prolyl hydroxylase domain-2 (PHD2) that hydroxylates the tumour enhancer hypoxia-inducible facto-1 alpha (HIF-1 $\alpha$ ). It is destroyed by Von Hippel Lindau tumour suppressor.16,17 Oestrogen receptor has anti proliferative effects on prostate. ER $\beta$ is sensitive to changes in tumour microenvironment. Hypoxic conditions and transforming growth factor beta (TGF $\beta$ ) signalling diminish the ER $\beta$ levels and alter its actions. This favours prostatic carcinoma progression. ${ }^{18,19}$ ER $\beta$ may play a significant role in prostate cell differentiation and proliferation. Initial phases of carcinogenesis and tumour growth can also be modulated with ER $\beta$. Expression of ER $\beta$ in prostatic carcinoma and re expression within metastasis also seen. ${ }^{20,21}$

The present study demonstrated ER $\beta$ expression in the epithelium of all 35 prostatic carcinoma cases (100\%), even though only 15 cases ( $42.9 \%$ ) showed stromal positivity of ER $\beta$. ER $\beta$ was present in the epithelium of 13 high grade and 22 intermediate grade carcinoma prostate $(100 \%)$. ER $\beta$ was present in the epithelium of BPH in 21 cases. (60\%). P value was $<0.001$. So, there is statistically significant association of epithelial expression of ER B and adenocarcinoma prostate. This denotes the relation between proliferative activity of prostate and ER $\beta$ expression. But ER $\beta$ expression in stroma does not show much difference between carcinoma and BPH with a $P$ value 0.075 . ER beta is well demonstrated in both neoplastic as well as hyperplastic proliferation of prostatic cells. ${ }^{20,22,23}$ This denotes the role of ER $\beta$ in the process of prostatic carcinoma and BPH.

ER $\alpha$ demonstrated positivity of epithelial tumour cells in only 3 cases (8.6\%). AII these were intermediate grade prostatic carcinoma. ER $\alpha$ expression in BPH was high 
compared to carcinoma prostate, ER $\alpha$ was expressed in the epithelium in 21 cases ( $60 \%$ ) of BPH. P value was $<0.001$. So, there is statistically significant association between ER $\alpha$ epithelial expression and BPH. ER $\alpha$ stromal positivity was expressed in a total of 10 cases (28.6\%) of adenocarcinoma. Out of these 10 cases, 2 were high grade carcinoma and 8 were intermediate grade carcinoma. In $\mathrm{BPH}$, stromal expression was seen in 9 cases (25.7\%). P value was 0.788 . As $P$ value was $>0.05$, there is no statistically significant association. In this study, even though the majority of prostatic carcinoma and BPH were negative for nuclear immune staining for ER alpha both in tumour and stromal cells, some cases demonstrated intense immune positivity.

ER $\alpha$ expression in carcinoma prostate is much lesser compared to ER $\beta$ expression. All the more, ER $\alpha$ positivity is more in intermediate grade tumours compared to high grade tumours. This is contrary to the ER $\beta$ expression. ER $\beta$ is more expressed in high grade tumours compared to intermediate grade tumors. ${ }^{24,25}$

BCL-2 protein functions as apoptosis suppressing protein. BCL2 protein is encoded by $B C L-2$ gene and is a member of BCL-2 family of regulator protein. BCL-2 derives its name from B-Cell Lymphoma as it was initially associated with $(14 ; 18)$ chromosomal translocations in follicular lymphoma. ${ }^{26,27}$ BCL2 is localized to the outer membrane of mitochondria. ${ }^{28}$ The pro-apoptotic proteins in the BCL-2 family including BAX and BAK act on mitochondrial membrane to promote the permeabilization and release of cytochrome $\mathrm{C}$ and reactive oxygen species (ROS) which signals the apoptotic cascade. ${ }^{29}$ These pro apoptotic proteins are activated by BH3-only proteins and are inhibited by BCL-2 and BCL-XL. ${ }^{22}$ BCL-2 protein inhibits apoptosis by interfering with Fas-associated protein with death domain (FADD) mediated activation of the caspase pathway. ${ }^{30}$ Apoptosis or programmed cell death is highly organized mechanism of cell death planned for removing senescent or potentially damaged cells. Over expression of BCL-2 can block apoptosis. In those cases, even the damaged cells will not undergo apoptosis, rather shall enter into cell cycle and proliferate. Later it will result in neoplastic proliferation. ${ }^{31} \mathrm{BCL}-2$ is expressed more in tumours showing high proliferation and invasive behaviour. Expression of BCL-2 is normally restricted to basal layer of normal \& hyperplastic prostatic epithelium. BCL-2 is over expressed in prostatic intraepithelial neoplasia and prostatic carcinoma. ${ }^{32}$

Out of the 35 cases of adenocarcinoma selected for this study, there were 13 high grade adenocarcinomas. All these 13 cases showed BCL- 2 positivity. Out of 22 cases of intermediate grade adenocarcinoma, only 2 showed BCL-2 positivity. Immunopositivity of BCL2 in high grade carcinoma prostate is significantly higher than in intermediate grade carcinoma with a $\mathrm{P}$ value $<0.0001$. The Chi square test value was 27.35 . This demonstrates high proliferative ability of BCL-2 neoplastic cells in high grade carcinoma prostate. Comparing with Gleason score and grade, it was found that all tumours with high Gleason score showed BCL-2 positivity, whereas prostatic carcinoma with low Gleason score showed BCL-2 positivity in $9.1 \%$ cases only. This suggests that BCL-2 positivity in prostatic carcinoma can be taken as a prognostic marker as its expression increases with grade of the tumour. In the study of Krajewska et al. BCL-2 positive neoplastic cells showed hormone insensitivity and was refractory to treatment. ${ }^{33}$
Out of 35 cases of $\mathrm{BPH}$, only 10 cases (28.6\%) showed BCL-2 positivity and 25 cases $(71.4 \%)$ were BCL-2 negative. Chi square test done to evaluate BCL-2 expression in adenocarcinoma and BPH. P value was 0.21 . Since $\mathrm{p}$ value > 0.05 , it was not statistically significant.

Some study demonstrated increased expression of BCL-2 in both carcinoma prostate and BPH. ${ }^{34,35}$ But in this study, BCL2 expression was low in BPH compared to carcinoma prostate. They also pointed out that BCL-2 expression was more in prostatic carcinoma with high Gleason score compared to low Gleason score, which was similar to the present study.

\section{CONCLUSIONS}

All prostatic carcinoma with a high Gleason grade showed BCL-2 positivity. Prostatic carcinoma with low Gleason grade showed BCL-2 positivity in $9.5 \%$ cases only. This suggests that BCL-2 positivity in prostatic carcinoma can be taken as a prognostic marker. ER $\beta$ demonstrated expression in the epithelial neoplastic cells in all cases of prostatic carcinoma. The ER $\beta$ expression in epithelium of prostate carcinoma is much higher compared to BPH with a significant $\mathrm{P}$ value $<0.01$. $\mathrm{BPH}$ also showed a high degree of positivity in epithelial neoplastic cells. This reveals the role of ER $\beta$ expression in proliferating and neoplastic prostate. ER $\alpha$ expression in prostate is much lesser compared to ER $\beta$ expression. ER $\alpha$ positivity is more in intermediate grade tumours compared to high grade tumours. Hence ER $\alpha$ expression cannot be considered as a marker for high grade prostatic carcinoma.

Data sharing statement provided by the authors is available with the full text of this article at jemds.com.

Financial or other competing interests: None.

Disclosure forms provided by the authors are available with the full text of this article at jemds.com.

I express my sincere gratitude to State Board of Medical Research (SBMR), Kerala for the financial aid for conducting this project.

\section{REFERENCES}

[1] Konishi N, Nakaoka S, Kitahori Y, et al. Immunohistochemical evaluation of estrogen receptor status in benign prostatic hypertrophy and in prostate carcinoma and the relationship to efficacy of endocrine therapy. Oncology 1993;50(4):259-63.

[2] Shweikert H, Tunn U, Habenicht U, et al. Effects of estrogen deprivation on human benign prostatic hyperplasia. J Ster Biochem Molec Biol 1993;44(4-6):5736.

[3] Matsushima H, Kitamura T, Gotu T, et al. Combined analysis with BCL - 2 and ERs immunostaining in prostatic carcinoma. Prostatic Cancer and Prostatic Diseases 2002;5:105-10.

[4] Tzifi F, Economopoulou C, Gourgiotis D, et al. The role of BCL - 2 family of apoptosis regulator proteins in acute and chronic leukemias. Adv Hematol 2012;2012:524308.

[5] Lee HR, Kim TH, Choi KC. Functiona and physiological roles of two types of estrogen receptors, ER $\alpha$ and ER $\beta$, 
identified by estrogen receptor knockout mouse. Lab Anim Res 2012;28(2):71-6.

[6] Al-Maghrabi JA, Hassan TM, Abdel-Meguid TA, et al. Expression of estrogen alpha and beta receptors in prostate cancer and hyperplasia: immunohistochemical analysis. African Journal of Urology 2010;16(3):79-87.

[7] Berchem GJ, Bosseler M, Sugars LY, et al. Androgens induce resistance to BCL-2-mediated apoptosis in LNCaPProstate cancer cells. Cancer Res 1995;55(4):735-41.

[8] Mobbs B, Johnson IE, Liu Y. Quantitation of cytosolic and nuclear estrogen and progesterone receptor in benign, untreated and treated malignant human prostatic tissue by radioligand binding and enzyme-immunoassays. Prostate 1990;16(3):235-44.

[9] Egevad L, Ahmed AS, Algaba F, et al. Standardisation of Gleason score among 337 European pathologists. Histopathology 2013;62(2):247-56.

[10] Raffo A, Perlman H, Chen M, et al. Overexpression of BCL2 proteins protects cancer cells from apoptosis. Cancer Res 1995;55(19):4438-45.

[11] Kim IY, Seong DH, Kim BC, et al. Raloxifene, a selective estrogen receptor modulator, induces apoptosis in androgen-responsive human prostate cancer cell line LNCaP through an androgen-independent pathway. Cancer Res 2002;62(13):3649-53.

[12] Fixmer T, Remberger $K$, Bonkhoff $H$. Differential expression of estrogen receptor beta (ERbeta) in human prostate tissue, premalignant changes and in primary, metastatic and recurrent prostatic adenocarcinoma. Prostate 2003;54(2):79-87.

[13] Royuela M, de Miguel MP, Bethencourt FR, et al. Estrogen receptors alpha and beta in the normal, hyperplastic and carcinomatous human prostate. J Endocrinol 2001;168(3):447-54.

[14] McPherson SJ, Ellem SJ, Simpson ER, et al. Essential role for estrogen receptor beta in stromal-epithelial regulation of prostatic hyperplasia. Endocrinology 2007;148(2):566-74.

[15] Nicholson TM, Sehgal PD, Drew SA, et al. Sex steroid receptor expression and localization in benign prostatic hyperplasia varies with tissue compartment. Differentiation 2013;85(4-5):140-9.

[16] Walton TJ, Li G, McCulloch TA, et al. Quantitative RT-PCR analysis of estrogen receptor gene expression in laser microdissected prostate cancer tissue. Prostate 2009;69(8):810-19.

[17] Han J, Sabbatini P, Perez D, et al. The EIB 19K protein blocks apoptosis by interacting with and inhibiting the p53 inducible and death promoting bax protein. Genes Dev 1996;10(4):461-77.

[18] Heldring N, Pike A, Andersson S, et al. Estrogen receptors: how do they signal and what are their targets. Physiol Rev 2007;87(3):905-31.

[19] Gabal SM, Habib FM, Helmy DO, et al. Expression of estrogen receptor beta (ER-B) in benign and malignant prostatic epithelial cells and its correlation with the clinicpathological features. J Egypt Natl Cancer Instit 2007;19(4):239-48.
[20] Morito K, Aomori T, Hirose T, et al. Interaction of phytoestrogens with estrogen receptors alpha and beta (II). Bio Pharm Bull 2002;25(1):48-52.

[21] Lai JS, Brown LG, True LD, et al. Metastases of prostate cancer express estrogen receptor-beta. Urology 2004;64(4):814-20.

[22] Zhu X, Leav I, Leung YK, et al. Dynamic regulation of estrogen receptor beta expression by DNA methylation during prostate cancer development and metastasis. Am J Pathol 2004;164(6):2003-12.

[23] Bosland MC. The role of estrogens in prostate carcinogenesis: a rationale for chemoprevention. Rev Urol 2005;7(Suppl 3):S4-10.

[24] Ricke WA, Wang Y, Kurita T, et al. Hormonal and stromal regulation of normal and neoplastic prosatic growth. Prog Mol Subcell Biol 2005;40:183-216.

[25] Teng J, Wang ZY, Jarrard DF, et al. Role of estrogen receptor alpha and beta in modulating urothelial cell proliferation. Endocr Relat Cancer 2008;15(1):351-64.

[26] Prins GS, Huang L, Birch L, et al. The role of estrogens in normal and abnormal development of the prostate gland. Ann N Y Acad Sci 2006;1089:1-13.

[27] Dey P, Jonsson P, Hartman J, et al. Estrogen receptors beta1 and beta2 have opposing roles in regulating proliferation and bone metastasis genes in the prostate cancer cell line PC3. Mol Endocrinol 2012;26(12):19912003.

[28] Bubendorf L, Sauter G, Moch H, et al. Prognostic significance of BCL-2 in clinically localized prostate cancer. Am J Pathol 1996;148(5):1557-65.

[29] Catz SD, Johnson JL. BCL-2 in prostate cancer: a minireview. Apoptosis 2003;8(1):29-37.

[30] Iemelynova AA, Grygorenko VM, Cheremuha SV, et al. Correlation between histological type and immunehistochemical profile of prostate cancer and gleason scale gradation. Exp Oncol 2009;31(4):246-9.

[31] Schlesinger PH, Gross A, Yin XM, et al. Comparison of the ion channel characteristics of proapoptotic BAX and antiapoptotic BCL-2. Proc Natl Acad Sci U S A 1997;94(21):11357-62.

[32] Yang J, Liu X, Bhalla K, et al. Prevention of apoptosis by BCL-2: release of cytochrome $c$ from mitochondria blocked. Science 1997:275(5303):1129-32.

[33] Krajewska M, Krajewski S, Epstein JI, et al. Immunohistochemical analysis of BCL-2, Bax, BCL-X and mcl-l expression in prostate cancers. Am J Pathol 1996;148(5):1567-76.

[34] Leav I, Lau KM, Adams JY, et al. Comparative studies of the estrogen receptors beta and alpha and androgen receptor in normal human prostate glands, dysplasia and in primary and metastatic carcinoma. Am J Pathol 2001;159(1):79-92.

[35] Pasquali D, Staibano S, Prezioso D, et al. Estrogen receptor beta expression in human prostate tissue. Mol Cell Endocrinol 2001;178(1-2):47-50. 